\title{
FAKTOR-FAKTOR YANG BERHUBUNGAN DENGAN PEMBERIAN ASI EKSLUSIF IADA IBU MEMPUNYAI BAYI DI WILAYAH KERJA PUSKESMAS KAYU JAO KABUPATEN SOLOK
}

\author{
KURNIATI MAYA SARI, WD \\ Pengajar Pada Akademi Keperawatan YPTK Solok
}

\begin{abstract}
Exclusive breastfeeding is breastfeeding only immediately after birth until the age of 6 months which is given as often as possible, unless drugs and vitamins can be given on medical indications. Based on the data obtained at the Solok District Health Office, the coverage of exclusive breastfeeding in 2016 decreased, the percentage of exclusive breastfeeding at KayuJao Health Center, Solok Regency, with a percentage of $39 \%$. The purpose of this study was to see the factors related to exclusive breastfeeding for mothers who have babies in the Work Area of the KayuJao Community Health Center, Solok Regency in 2017. This type of research is descriptive analytic. This research was conducted on 12-21 December 2017, with the sampling technique using Simple Random Sampling and obtained a total sample of 51 respondents. The data were collected and then the data was processed using a computerized system and then analyzed using univariate and bivariate analysis and then interpreted. The results showed that there was a significant relationship between experiences with exclusive breastfeeding with $p$-value $=0.046<(p<0.005))$, there was a significant relationship between maternal occupation and exclusive breastfeeding with $p$-value $=0.042<(p<0.005)$ and There is a significant relationship between the support of health workers and exclusive breastfeeding for infants aged 7-12 months with $p$-value $=0.001<(p<0.005)$ at KayuJao Health Center, Solok Regency, 2017. It is hoped that respondents with poor experience should seek information about exclusive breastfeeding, such as asking people around and to health workers, especially mothers who are primiparous because they have never breastfed. Respondents should be more willing to seek information about exclusive breastfeeding even though it is influenced by the mother's education. low, such as asking questions or in counseling at posyandu and in classes for pregnant women. Working mothers should be able to leave breast milk by expressing breastmilk because the expressed breast milk will not spoil even for a long time. For support, health workers should provide support to mothers who have babies, including exclusive breastfeeding, such as providing counseling on exclusive breastfeeding to classes for pregnant women, and providing counseling at posyandu and also health workers must also guide mothers in providing nutritional intake and must cover all maternal and child health needs.
\end{abstract}

Keywords: breastfeeding, maternal, child health needs.

\section{A. Pendahuluan}

Tujuan pembangunan kesehatan menuju Indonesia Sehat 2025 adalah meningkatnya kesadaran, kemauan, dan kemampuan hidup sehat bagi setiap orang agar peningkatan derajat kesehatan masyarakat yang setinggi-tingginya dapat terwujud, melalui terciptanya masyarakat, bangsa dan Negara Indonesia yang ditandai oleh penduduknya yang hidup dengan perilaku dan dalam lingkungan sehat, memiliki kemampuan untuk menjangkau pelayanan kesehatan yang bermutu, secara adil dan merata, serta memiliki derajat kesehatan yang setinggi-tingginya di seluruh wilayah Republik Indonesia. Salah satunya dengan pemberian ASI Eksklusif kepada bayi sampai umur 6 bulan. (Depkes RI, 2013). ASI Eksklusif adalah pemberian Air Susu

EISSN 2657-0289 Lembaga Penelitian dan Penerbitan Hasil Penelitian Ensiklopedia 11


Ibu saja kepada bayi umur 0-6 bulan tanpa diberikan makanan atau minuman tambahan selain obat untuk terapi (pengobatan penyakit). Pemberian ASI eksklusif adalah pemberian ASI saja sejak bayi dilahirkan sampai sekiatr usia 6 bulan. Selama itu bayi tidak diharapkan mendapatkan tambahan cairan lain, seperti susu formula, air jeruk, air teh, madu, air putih. Pada makanan tambahan seperti pisang, biskuit. bubur nasi, tim,dan sebagainya. ASIeksklusif diharapkan dapat diberiakan sampai 6 bulan. Pemberian ASI secara benar akan dapat mencukupi kebutuhan bayi sampai usia enam bulan,tanpa makanan pendamping. Di atas usia 6 bulan, bayi memerlukan makanan tambahan tetapi pemberian ASI dapat dilanjtkan sampai ia berumur 2 tahun. (Anik Maryunani , 2012).

Anak merupakan aset bangsa yang sangat berharga dan menjadi penerus cita-cita bangsa yang nantinya akan menjadi pemimpin di masa depan yang meneruskan kemajuan bangsa dan negara. Namun sebagai aset berharga ,tidak semua anak memperoleh haknya untuk dapat berkembang sebagaimana layaknya anak pada umumnya. Hal ini salah satunya dialami oleh anak-anak yang ketika ia masih bayi tidak diberikan ASI oleh ibunya. ASI merupakan nutrisi dengan kualitas dan kwantitas yang terbaik bagi bayi, pemberian ASI di Indonesia saat ini belum dilaksanakan sepenuhnya, karena upaya meningkatkan perilaku menyusui pada ibu yang memiliki bayi khususnya pemberian ASI yang masih kurang.(Ayun Nif'ah,Firdaus, 2014) Bayi yang tidak mendapatkan ASI eksklusif selama 6 bulan lebih, dapat mengembangkan berbagai penyakit menular, termasuk infeksi telinga, diare, penyakit pernafasan dan memiliki riwayat sering sakit. Serta, bayi yang tidak diberi ASI memiliki 21 persen lebih tingkat kematian.

Studi di American Academy of Pediatrics, menunjukkan, bahwa bayi yang tidak diberi ASI memiliki tingkat kematian yang tinggi, dan tingkat lebih tinggi terkena leukemia, kelebihan berat badan dan obesitas, tingkat kolesterol serta asma. (Depkes RI, 2013). Perilaku pemberian Air Susu Ibu (ASI) Eksklusif di dunia masih rendah, berdasarkan data United Nations Children's Fund ( UNICEF) tahun 2015 hanya 40\% bayi usia kurang dari 6 bulan yang mendapatkan ASI secara Eksklusif di seluruh dunia, di dunia cakupan rata-rata pemberian ASI Eksklusif sekitar 38\%. Lancet Breastfeeding Series 2016 menyebutkan ASI Eksklusif di Indonesia meningkat dari sebelumnya 38\% naik menjadi 65\%.(Pepi Hapitria ). Data Dinas Kesehatan Provinsi Sumatera Barat indikator pemberian ASI eksklusif mengalami kenaikan tiap tahunnya namun belum mencapai target pada tahun 2015 ialah sebesar 83,00. (Nurul Aini).

Sementara itu menurut data yang didapatkan di Dinas Kesehatan Kabupaten Solok. Cakupan pemberian ASI Eksklusif di Kabupaten Solok pada tahun 2016 terjadi mencapai angka $71 \%$ dari standar pemerintah Indonesia yaitu $42 \%$. (Dinkes Solok ) yang paling bermasalah dari 18 puskesmas adalah puskesmas Kayu Jao. Ada beberapa faktor yang dapat mempengaruhi ibu dalam pemberian ASI pada bayi mereka. Faktor-faktor tersebut adalah usia, pendidikan, jumlah anak, ASI ekslusif, pengalaman menyusui, usia anak, dan jenis kelamin anak. (Beta Woro Hastuti, 2015). Faktor- faktor lain yang dapat mempengaruhi ibu dalam pemberian ASI pada bayi mereka. Faktor-faktor tersebut adalah faktor pencetus yang terdiri atas umur, pendidikan, pengetahuan, sikap dan keterpaparan informasi, faktor pemungkin yang terdiri atas ketersediaan fasilitas, lama meninggalkan bayi, dan ada faktor penguat yang terdiri atas dukungan suami, dukungan pengasuh, dukungan atasan langsung, dan dukungan tenaga kesehatan. ( Giri Inayah Abdullah, 2013). 
Hal ini didukung oleh hasil penelitian yang dilakukan oleh Rasti Oktara ( 2013 ) tentang pengetahuan, pendidikan, usia, pekerjaan ibu, peran petugas kesehatan, jumlah anak dan promosi susu formula. Dari beberapa faktor diatas tidak semua faktor dijadikan variabel penelitian, yang dijadikan variabel penelitian yaitu pengalaman, pekerjaan, dan dukungan petugas kesehatan.

\section{B. Metodologi Penelitian}

Penelitian ini bersifat deskriptif analitik dengan pendekatan cross sectional. Data yang diperoleh adalah data sekunder yang dikumpulkan dari laporan petugas program dipuskesmas. Dalam penelitian ini Dalam penelitian ini teknik pengambilan sampel yang digunakan adalah pengambilan sampel secara acak sederhana (simple random sampling)yaitu ibu yang mempunyai bayi usia 7-12 bulan yang berjumlah 51 orang.

\section{Hasil dan Pembahasan \\ 1. Hasil}

\section{Pemberian ASI Ekslusif}

Distribusi Frekuensi Responden Berdasarkan Pemberian ASI Eksklusif Pada Bayi usia 7-12 Bulan Di puskesmas Kayu Jao Kabupaten Solok

\begin{tabular}{|l|l|c|c|}
\hline No & Pemberian ASI Eksklusif & Frekuensi & \% \\
\hline 1 & Tidak diberikan & 30 & 58,8 \\
\hline 2 & Diberikan & 21 & 41,2 \\
\hline \multicolumn{2}{|c|}{ Jumlah } & $\mathbf{5 1}$ & $\mathbf{1 0 0}$ \\
\hline
\end{tabular}

Bersadarkan table diatas dilihat bahwa lebih dari sebagian (58,8\% ) responden tidak memberikan ASI Eksklusif di wilayah kerja Puseksmas Kayu Jao Kabupaten Solok.

\section{Pengalaman Ibu}

Distribusi Frekuensi Responden Berdasarkan Pengalaman Ibu yang Memiliki Bayi Usia 7-12 Bulan Di Puskesmas Kayu Jao Kabupaten Solok

\begin{tabular}{|l|l|c|c|}
\hline No & Pengalaman & Frekuensi & \% \\
\hline 1 & Kurang baik & 21 & 41,2 \\
\hline 2 & Baik Jumlah & 30 & 58,8 \\
\hline \multicolumn{2}{|c|}{ J1 } & $\mathbf{1 0 0}$ \\
\hline
\end{tabular}

Berdasarkan tabel, terlihat bahwa lebih dari sebagian $(58,8 \%)$ responden mempunyai pengalaman yang baik dalam pemberian ASI Eksklusif di Wilayah Kerja Puskesmas Kayu Jao.

\section{Pekerjaan}

Distribusi Frekuensi Responden Berdasarkan Pekerjaan Ibu yang Memiliki Bayi Usia 7-12 Bulan Di Puskesmas Kayu Jao Kabupaten Solok

\begin{tabular}{|l|l|c|c|}
\hline No & Pekerjaan & Frekuensi & \% \\
\hline 1 & Bekerja & 31 & 60,8 \\
\hline 2 & Tidak bekerja & 20 & 39,2 \\
\hline \multicolumn{2}{|c|}{ Jumlah } & $\mathbf{5 1}$ & $\mathbf{1 0 0}$ \\
\hline
\end{tabular}

Berdasarkan tabel diatas, dilihat bahwa lebih dari sebagian (60,8\%) responden dikategorikan bekerja di wilayah kerja Puskesmas Kayu Jao Kabupaten Solok.

\section{Dukungan Petugas}

Distribusi Frekuensi Responden Berdasarkan Dukungan Petugas Kesehatan Terhadap Pemberin ASI Ekslusif Pada Bayi Usia 7-12 Bulan Di Puskesmas Kayu Jao Kabupaten Solok 


\begin{tabular}{|c|c|c|c|}
\hline No & $\begin{array}{ll}\text { Dukungan } & \text { Petugas } \\
\text { Kesehatan } & \end{array}$ & Frekuensi & $\%$ \\
\hline 1 & Tidak ada dukungan & 15 & 29,4 \\
\hline 2 & Ada dukungan & 36 & 70,6 \\
\hline & Jumlah & 51 & 100 \\
\hline
\end{tabular}

Berdasarkan tabel diatas dapat dilihat bahwa lebih dari sebagian $(70,6 \%)$ responden ada dukungan petugas kesehatan tentang pemberian ASI Eksklusif di Wilayah Kerja Puskesmas Kayu Jao Kabupaten Solok.

\section{Hubungan Pengalaman Ibu dengan Pemberian ASI Eksklusif Pada Bayi Usia}

\section{7-12 Bulan Di Puskesmas Kayu Jao Kabupaten Solok}

Distribusi Frekuensi Responden Berdasarkan Hubungan Pengalaman Ibu Dengan Pemberian ASI Eksklusif Pada Bayi Usia 7-12 Bulan Di Puskesmas Kayu Jao Kabupaten Solok

\begin{tabular}{|l|c|c|c|c|c|c|}
\hline \multirow{2}{*}{ Pengalaman } & \multicolumn{6}{|c|}{ Pemberian ASI Ekslusif } \\
\cline { 2 - 7 } & \multicolumn{2}{|c|}{ Tidak diberikan } & \multicolumn{2}{c|}{ Diberikan } & \multicolumn{2}{c|}{ Total } \\
\hline & F & $\mathbf{\%}$ & F & \% & F & \% \\
\hline Kurang baik & 16 & 76,2 & 5 & 23,8 & 21 & 100 \\
\hline Baik & 14 & 46,7 & 16 & 53,3 & 30 & 100 \\
\hline Total & $\mathbf{3 0}$ & $\mathbf{5 8 , 8}$ & $\mathbf{2 1}$ & $\mathbf{4 1 , 2}$ & $\mathbf{5 1}$ & $\mathbf{1 0 0}$ \\
\hline \multicolumn{2}{r}{$\mathrm{P}=0,046$}
\end{tabular}

Berdasarkan tabel diatas dari 21 orang resonden yang memiliki pengalaman kurang baik lebih dari sebagian ( $76,2 \%$ ) responden tidak memberikan ASI Ekslusif sedangkan dari 30 responden yang memiliki pengalaman baik lebih dari sebagian $(53,3 \%)$ memberikan ASI Eksklusif. Dari hasil uji statistic yang dilakukan ternyata diperoleh pvalue $0,046<0,05$ berarti ada hubungan yang bermakna antara pengalaman ibu dengan pemberian ASI Eksklusif pada bayi. Dengan Odds Ratio $(3,6)$ artinya responden yang berpengalaman baik berpeluang 4 kali memberikan ASI Eksklusif di bandingkan ibu yang berpengalaman kurang baik.

\section{Hubungan Pekerjaan Ibu Dengan Pemberian ASI Eksklusif Pada Bayi Usia 7-} 12 Bulan Di Puskesmas Kayu Jao Kabupaten Solok

Distribusi Frekuensi Responden Berdasarkan Hubungan Pekerjaan Ibu Dengan Pemberian ASI Eksklusif Pada Bayi Usia 7-12 Bulan Di Puskesmas Kayu Jao Kabupaten Solok

\begin{tabular}{|l|c|c|c|c|c|c|}
\hline \multirow{2}{*}{ Pekerjaan } & \multicolumn{6}{|c|}{ Pemberian ASI Eksklusif } \\
\cline { 2 - 7 } & \multicolumn{2}{|c|}{ Tidak diberikan } & \multicolumn{2}{|c|}{ Diberikan } & \multicolumn{2}{c|}{ Total } \\
\cline { 2 - 7 } & $\mathbf{F}$ & $\mathbf{\%}$ & $\mathbf{G}$ & $\mathbf{\%}$ & $\mathbf{F}$ & $\mathbf{\%}$ \\
\hline Bekerja & 22 & 71,0 & 9 & 29,0 & 31 & 100 \\
\hline Tidak bekerja & 8 & 40,0 & 12 & 60,0 & 20 & 100 \\
\hline Total & $\mathbf{3 0}$ & $\mathbf{5 8 , 8}$ & $\mathbf{2 1}$ & $\mathbf{4 1 , 2}$ & $\mathbf{5 1}$ & $\mathbf{1 0 0}$ \\
\hline
\end{tabular}

$$
\mathrm{P}=0,042 \quad \mathrm{OR}=3,6
$$

Berdasarkan tabel diatas diketahui bahwa dari 31 orang resonden yang bekerja sebagian $(71,0 \%)$ responden tidak memberikan ASI Eksklusif sedangkan dari 20 responden yang tidak bekerja lebih dari sebagian (60\%) memberikan ASI Eksklusif. Dari uji statistic yang dilakukan ternyata diperoleh pvalue $0,042<0,05$ berarti ada hubungan yang bermakna antara pekerjaan ibu dengan pemberian ASI Eksklusif pada 
bayi. Dengan Odds Ratio $(3,6)$ artinya responden yang bekerja berpeluang 4 kali memberikan ASI Eksklusif dibandingkan responden yang tidak bekerja.

\section{Hubungan Dukungan Petugas Kesehatan Dengan Pemberian ASI Eksklusif Pada Bayi Usia 7-12 Bulan Di Puskesmas Kayu Jao Kabupaten Solok \\ Distribusi Frekuensi Responden Berdasarkan Hubungan Dukungan Petugas Kesehatan Dengan Pemberian ASI Eksklusif Pada Bayi Usia 7-12 Bulan Di PuskesmasKayu Jao Kabupaten Solok}

\begin{tabular}{|l|c|c|c|c|c|c|}
\hline \multirow{2}{*}{$\begin{array}{l}\text { Dukungan petugas } \\
\text { kesehatan }\end{array}$} & \multicolumn{6}{|c|}{ Pemberian ASI Eksklusif } \\
\cline { 2 - 7 } & \multicolumn{2}{|c|}{ Tidak diberikan } & \multicolumn{2}{|c|}{ Diberikan } & \multicolumn{2}{c|}{ Total } \\
\cline { 2 - 7 } & $\mathbf{F}$ & $\mathbf{\%}$ & $\mathbf{F}$ & $\mathbf{\%}$ & $\mathbf{f}$ & $\mathbf{\%}$ \\
\hline Tidak ada dukungan & 14 & 93,3 & 1 & 6,7 & 15 & 100 \\
\hline Ada dukungan & 16 & 44,4 & 20 & 55,6 & 36 & 100 \\
\hline Total & $\mathbf{3 0}$ & $\mathbf{5 8 , 8}$ & $\mathbf{2 1}$ & $\mathbf{4 1 , 2}$ & $\mathbf{5 1}$ & $\mathbf{1 0 0}$ \\
\hline
\end{tabular}

$\mathrm{P}=0,001 \quad \mathrm{OR}=17,5$

Berdasarkan tabel diatas dari 15 orang resonden yang tidak ada dukungan petugas kesehatan sebagian besar $(93,3 \%)$ responden tidak memberikan ASI Eksklusif sedangkan dari 36 responden yang ada dukungan dari petugas kesehatan lebih dari sebagian $(55,6 \%)$ memberikan ASI Eksklusif. Dari uji statistic yang dilakukan ternyata diperoleh pvalue $0,001<0,05$ berarti ada hubungan yang bermakna antara dukungan petugas kesehatan dengan pemberian ASI Ekslusif pada bayi. Dengan Odds Ratio $(17,5)$ artinya responden yang ada dukungan petugas kesehatan berpeluang 17 kali memberikan ASI Eksklusif dibandingkan responden tidak ada dukungan dari petugas kesehatan.

\section{Pembahasan}

\section{Hubungan Pengalaman Responden dengan Pemberian ASI Ekslusif Pada Bayi} Usia 7-12 Bulan Di Wilayah Kerja Puskesmas Kayu Jao Kabupaten Solok

Dari hasil uji statistic yang dilakukan ternyata diperoleh pvalue 0,046<0,05 berarti ada hubungan yang bermakna antara pengalaman ibu dengan pemberian ASI Eksklusif pada bayi. Dengan Odds Ratio $(3,6)$ artinya responden yang berpengalaman baik berpeluang 4 kali memberikan ASI Eksklusif di bandingkan ibu yang berpengalaman kurang baik. Pengalaman menyusui adalah gambaran pengalaman ibu ketika menyusui kelahiran yang terakhir termasuk status pembeian ASI Ekslusif. Dikutip dari buku Notoadmojo mengungkapakan bahwa pengalaman merupakan guru yang baik, yang menjadi sumber pengetahuan. Pengalaman menyusui yang dinilai baik ketika seorang ibu memiliki pengalaman menyusui sebelumnya yang tergolong ASI Esklsuisf dan tidak ada kesulitan selama menyusui. Pengalaman yang diperoleh akan mempengaruhi ibu dan akhirnya dapat terbentuk respon yang berupa perilaku untuk memberikan ASI. Pengalaman menyusui sebelumnya menentukan keputusan untuk memberikan ASI.

Penelitian ini sejalan dengan penelitian yang dilakukan oleh Rina Qoidatul Awaliyah tentang pengalaman ibu terhadap pemberian ASI Eksklusif. Hasil penelitian menunjukkan bahwa ada hubungan yang bermakna pvalue $=0,056<(\mathrm{p}<0,005)$ antara pengalaman dengan pemberian ASI Eksklusif. Menurut Mursyida (2013) mengungkapkan bahwa ada hubungan antara pengalaman dengan pemberian ASI Eksklusif, prevalensi menyusui eksklusif meningkat dengan bertambahnya jumlah 
anak. Kenyataan dilapangan dari hasil data yang dikumpulkan menunjukkan bahwa responden yang memiliki pengalaman kurang baik ternyata tidak memberikan ASI Eksklusif, hal ini di sebabkan oleh beberapa kondisi seperti bayi tidak kenyang hanya dengan pemberian ASI saja karena setelah di susui bayi tetap menangis dan setelah diberi makanan tambahan bayinya baru diam dan ada ASI ibu yang tidak keluar dan juga ibu yang pertama kali menyusui tidak memberikan ASI Eksklusif ini di sebabkan juga oleh faktor pendidikan ibu yang rendah dan kurangnya informasi tentang pemberian ASI Eksklusif dari orang sekitar atau dari petugas kesehatan.

\section{Hubungan Pekerjaan Responden dengan Pemberian ASI Eksklusif Pada Bayi Usia 7-12 Bulan Di Wilayah Kerja Puskesmas Kayu Jao Kabupaten Solok}

Dari uji statistic yang dilakukan ternyata diperoleh pvalue $0,042<0,05$ berarti ada hubungan yang bermakna antara pekerjaan ibu dengan pemberian ASI Eksklusif pada bayi. Dengan Odds Ratio $(3,6)$ artinya responden yang bekerja berpeluang 4 kali memberikan ASI Ekslusif dibandingkan responden yang tidak bekerja. Bekerja adalah aktifitas ibu diluar dan di dalam rumah yang menghasilkan uang. Bekerja umumnya merupakan kegiatan yang menyita waktu bagi ibu-ibu yang mempunyai pengaruh terhadap kehidupan keluarga. Bagi ibu yang bekerja, menyusui tidak perlu dihentikan. Ibu bekerja harus tetap memberikan ASI-nya dan jika memungkinkan bayi dapat dibawa ke tempat kerja. Apabila tidak memungkinkan, ASI dapat diperah kemudian disimpan.

Penelitian ini sejalan dengan penelitian yang dilakukan oleh oleh Fitriani Badriah (2017) tentang hubungan pekerjaan ibu terhadap pemberian ASI Eksklusif pada bayi. Hasil penelitian menunjukkan bahwa ada hubungan yang bermakna pvalue $=0,018<$ $(\mathrm{p}<0,005)$ antara pekerjaan dengan pemberian ASI Eksklusif. Hal ini terjadi karena pekerja wanita yang melahirkan, memberikan ASI Eksklusif merupakan suatu dilema,karena masa cuti terlalu singkat dibandingkan masa menyusui, sehingga mereka akan memberikan susu formula sebagai pengganti ASI Eksklusif.

Kenyataan yang ditemukan di lapangan dari hasil data yang di kumpulkan menunjukkan bahwa responden memiliki pekerjaan tidak memberikan ASI Eksklusif, karena ibu yang bekerja cenderung memilki waktu yang sedikit untuk menyusui anaknya akibat kesibukan bekerja selain itu bagi ibu yang terikat dengan suatu instalasi masa cuti ibu yang terlalu singkat dibandingkan masa menyusui juga menjadi suatu permasalah sehingga mereka akan memberikan susu formula sebagai pengganti ASI eksklusif setelah ibu mulai bekerja lagi, dan juga ibu yang bekerja tidak memeras ASI nya untuk ditinggalkan kepada bayinya selama ibu tidak di rumah sehingga bayinya hanya diberikan susu formula.

\section{Hubungan Dukungan Petugas Kesehatan dengan Pemberian ASI Eksklusif Pada Bayi Usia 7-12 Bulan Di Wilayah Kerja Puskesmas Kayu Jao Kabupaten Solok}

Dari uji statistic yang dilakukan ternyata diperoleh pvalue $0,001<0,05$ berarti ada hubungan yang bermakna antara dukungan petugas kesehatan dengan pemberian ASI Eksklusif pada bayi. Dengan Odds Ratio $(17,5)$ artinya adanya dukungan petugas kesehatan berpeluang 17 kali memberikan ASI Ekslusif dibandingkan tidak ada dukungan dari petugas kesehatan. Dukungan petugas kesehatan adalah melindungi dan meningkatkan perilaku ibu menyusui secara ekslusif maupun menyusukan bayi sampai 2 tahun dan membantu ibu memecahkan masalah hambatan persoalan yang berhubungan dengan menyusui. (Risa Pritriani,S.ST.,M.KES,2014:25). 
Hal ini sejalan dengan penelitian yang dilakukan oleh Pepi Hapitria (2017) tentang hubungan antara dukungan suami dan dukungan tenaga kesehatan terhadap perilaku pemberian ASI eksklusif di wilayah kerja puskesmas cangkol kota cirebon tahun 2017. Hasil penelitian menunjukkan bahwa ada hubungan yang bermakna pvalue $=0,023(\mathrm{p}<0,005)$ antara dukungan petugas kesehatan dengan pemberian ASI Eksklusif. Kenyataan yang ditemukan di lapangan dari hasil data yang di kumpulkan bahwa responden yang tidak mendapat dukungan petugas kesehatan ternyata tidak memberikan ASI Eksklusif, berdasarkan kuesioner masih ada petugas kesehatan yang tidak memberikan dukungan khususnya kepada ibu-ibu yang memiliki bayi seperti tidak adanya pengarahan atau penyuluhan tentang pemberian ASI Eksklusif di tempat pelayanan kesehatan seperti di posyandu dan petugas kesehatan tidak mencakup semua kebutuhan kesehatan bagi ibu dan bayinya seperti tidak ikut membimbing ibu dalam pemberian asupan gizi kepada bayinya. Selain itu letak puskesmas yang juga jauh dari tempat tinggal warga menjadi suatu permasalahan.

\section{Penutup}

Lebih dari sebagian $(58,8 \%)$ responden tidak memberikan ASI Eksklusif pada bayi 7-12 bulan di Wilayah Kerja Puskesmas Kayu Jao Kabupaten Solok. Lebih dari sebagian $(58,8 \%)$ responden memiliki pengalaman yang baik di Wilayah Kerja Puskesmas Kayu Jao Kabupaten Solok. Lebih dari sebagian $(60,8 \%)$ responden bekerja diluar rumah di Wilayah Kerja Puskesmas Kayu Jao Kabupaten Solok. Lebih dari sebagian $(70,6 \%)$ responden memiliki dukungan petugas kesehatan terhadap pemberian ASI Eksklusif di Wilayah Kerja Puskesmas Kayu Jao Kabupaten Solok. Terdapat hubungan yang bermakna antara pengalaman dengan pemberian ASI Eksklusif pada bayi usia 7-12 bulan dengan pvalue $=0,046<(\mathrm{P} \alpha=<0,05)$ di Wilayah Kerja Puseksmas Kayu Jao Kabupaten Solok. Terdapat hubungan yang bermakna antara pekerjaan dengan pemberian ASI Eksklusif pada bayi usia 7-12 bulan dengan pvalue $=0,042<(\mathrm{P} \alpha=<0,05)$ di Wilayah Kerja Puseksmas Kayu Jao Kabupaten Solok. Terdapat hubungan yang bermakna antara dukungan petugas kesehatan dengan pemberian ASI Eksklusif pada bayi usia 7-12 bulan dengan pvalue $=0,001<(\mathrm{P} \alpha=<$ 0,05) di Wilayah Kerja Puseksmas Kayu Jao Kabupaten Solok

\section{Daftar Pustaka}

Abdullah Inayah Giri, 2013, Determinan Perilaku Pemberian Air Susu Ibu Eksklusif Pada Ibu Pekerja, Jurnal Kesehatan Mayarakat Nasional Vol,7 No. 7. Februari 2013

Aini Nurul, 2017, Hubungan Riwayat Pola Pemberian ASI Eklusif dengan Perkembangan Anak Pra sekolah di Kecamatan Koto Tangah Kota Padang, Jurnal Kesehatan Andalas,2017:6(2)

Astuti Woro Beta,2015, Hubungan Pengalaman Menyusui dan Tingkat Pendidikan ibu dengan Pemberian ASI Ekslusif di Kelurahan Barukan,Kecamatan Manissenggo,Kabupaten Klaten, JKK, Vol.6.No.4.Januari-April 2015

Awaliyah Quidatul Rina,2016, faktor yang berhubungan dengan pemberian ASI eksklsusif oleh ibu di Ponkesdes Pilang Kabupaten Sidoarjo, 2016 :61

Badriyah Fitriyani, 2017, hubungan pekerjaan ibu terhadap pemberian ASI Eksklusif pada bayi, journal Endurance : 116

cadwell Karin, Turner Cindy -Maffei,2011, Buku Saku Manajemen Laktasi, Jakarta : EGC 
Departemen Kesehatan RI,2013, Ibu Bekerja Tetap Memberikan Air Susu Ibu (ASI), Ditjen Bina Kesehatan Masyarakat, Jakarta

Ditjen Bina gizi Dan Kesehatan Ibu dan Anak Kementrian Kesehatan RI,2013, Strategi Pemberian Makanan Bayi dan Anak, Kementrian Kesehatan RI,Jakarta

Departemen Kesehatan RI,2013, Ibu Bekerja Tetap Memberikan Air Susu Ibu (ASI), Ditjen Bina Kesehatan Masyarakat, Jakarta

Departemen Kesehatan RI,2014, Materi Penyuluhan Pemberian Air Susu Ibu dan Makanan Pendamping ASI, Ditjen Bina Gizi dan Kesehatan Ibu dan Anak Direktorat Bina Gizi, Jakarta

Dewi Lia Nanny Vivian dan Sunarsih Tri, 2011, Asuhan Kebidanan Pada Ibu Nifas, Jakarta : Salemba Medika

Firmansyah Nurhuda dan Mahmudah,2012, Pengaruh Karakteristik (pendidikan, pekerjaan,) Pengetahuan dan Sikap Ibu Menyusui Terhadap Pemberian ASI Ekslusif di Kabupaten Tuban, Jurnal Biometrika dan Kependudukan,Volume 1 Nomor 1, Agustus 2012:62-71

Hopitria Pepi,2017, Hubungan antara Dukungan Suami dan Dukungan Tenaga Kesehatan terhadap Perilaku Pemberian ASI Eklusif di Wilayah Kerja Puskesmas Congkol Kota Cirebon tahun 2017,Dosen Program Studi Kebidanan Cirebon

Maryunani Anik,2012, Inisiasi Menyusui Dini ASI Eksklusif dan Manajemen Laktasi, Jakarta : Trans Media Info

Monika F.B ., 2014, Konsep Dasar dan Menyusui , Jakarta:Naura Books

Nif'ah Ayun, Pengaruh Pemberian ASI terhadap Perkembangan Anak usia 6-12 bulan di Rw 04 Desa Sambibulu Kecamatan Taman Sidoarjo

Nursalam,2011, Konsep dan Penerapan Metodologi Penelitian Ilmu Keperawatan, Jakarta : Salemba Medika

Notoadmodjo Soekidjo, 2012, Metodologi Penelitian Kesehatan, Jakarta : Rineka cipta

Oktara Rasti, 2013. Gambaran Pemberian ASI Ekslusif pada Ibu Bekerja di Desa Serua Indah,Kecamatan Jombang, Tangerang Selatan, Jurnal Kesehatan Reproduksi Vol.4 No.1. April 2013:30-40

Pitriani Risa.S.S.T. M.Kes dan Andriyani Rika.S.S.T.M.Kes, 2012, Asuhan Kebidanan Ibu Nifas Normal (ASKEB III), Yogyakarta : Budi Utama

Sunarti Sri,S.K.M.M.Si, 2013, Panduan Menyusui Praktis dan Lengkap, Jakarta : Macanan Jaya Cemerlang

Widdefrita,2013, Peran Petugas Kesehatan dan Status Pekerjaan Ibu dengan Pemberian ASI Ekslusif, Jurnal Kesehatan Masyarakat, September 2013- Maret 2014, Vol 8 No.1

Yuharti Nurheti,2010, Keajaiban ASI-Makanan Terbaik Untuk Kesehatan, Kecerdasan, dan Kelincahan si Kecil, Yogyakarta : Andi Offset 